\title{
A model for evaluating the economic feasibility of small-scale biodiesel production systems for on-farm fuel usage
}

Johan Pienaar ${ }^{1}$, Alan C Brent ${ }^{2 *}$

1. Graduate School of Technology Management, University of Pretoria, Pretoria, 0002, South Africa

2. Centre for Renewable and Sustainable Energy Studies, School of Public Leadership, Stellenbosch University, Stellenbosch, 7600, South Africa

* Tel: $\quad+27218813952$

Fax: $\quad+27218813294$

E-mail: acb@sun.ac.za

\begin{abstract}
Farming operations in Africa have, in general, not adopted small-scale biodiesel production technology well for on-farm fuel usage. This is mainly due to the lack of an acceptable method to assess the economic feasibility of constructing small-scale biodiesel production facilities, and the impact of such operations on existing farming production processes. The research study summarised in this paper subsequently set out to develop a model, termed the Biodiesel Production System Optimisation Model (BPSOM), which predicts the cost of producing biodiesel on a smallscale, and optimises on-farm production processes to maximise profits. The model was validated using a South African case study to evaluate the predicted cost of biodiesel per litre produced, and the economic impact of a small-scale facility on the production profits of a farm. A proxy indicator, profit per hectare cultivated land, is introduced to measure the impact. BPSOM predicts a positive profit increase of $33 \%$ for the specific farm case study, which proves the economic potential of small-scale biodiesel production facilities for fuel usage at farm level in Africa.
\end{abstract}




\section{Keywords}

Bioenergy; biofuel; biodiesel; financial model; economic feasibility; farming; Africa.

\section{Introduction}

Biodiesel is a renewable energy source that is manufactured by the catalytic reaction of plant oils with methanol. The chemical reaction is commonly referred to as transesterification [1,2], and is generally described as [3]:

$100 \mathrm{~kg}$ of oil $+10 \mathrm{~kg}$ of methanol $\rightarrow 100 \mathrm{~kg}$ of biodiesel $+10 \mathrm{~kg}$ of glycerol

It involves breaking the more complex triglyceride oil molecules into single-chain molecules and a residual glycerol molecule. The two products are then separated and purified to form biodiesel and glycerol. Methanol is produced as a by-product and is removed for reuse by distillation in the purification process. In practice, sodium or potassium hydroxide is normally used as the catalyst in the reaction. The most common plant oils that are used for the production of biodiesel are soybean and rapeseed oil, but canola, corn and cottonseed oil can also be used. Even animal fats and recycled restaurant oils are being used [4].

Biodiesel has similar properties to that of conventional petroleum diesel; it can be readily blended with petroleum diesel and is therefore suitable to be used in diesel engines without any major modifications to the engines [5]. Biodiesel also has the advantage that it has a higher level of engine lubricity and subsequently contributes to overall engine life [5], and is a clean burning fuel that results in a reduction of harmful engine emissions [4]. The major disadvantages of biodiesel are its different gelling temperatures to conventional petroleum diesel, which may cause blockages in the engine fuel system under cold operating temperatures, and its lower specific energy value, which results in up to five percent loss in engine power [4]. 
Internationally the biodiesel industry is growing rapidly [6], because biodiesel reduces the dependency on petroleum oils and may become more cost competitive with petroleum diesel as crude oil prices rise [5]. In South Africa, large-scale biodiesel production is consequently being investigated based on a $2 \%$ blend with conventional diesel [7]. On a smaller scale, communities and farmers are investigating the potential biodiesel provides as an alternative local market for their agricultural crops. For example, in the North West Province of the country, a farmer has commissioned a small-scale plant that utilises sunflower oil as feedstock. A final production cost per litre of biodiesel is reported as R 4.15 [8], or less than 60 US cents, as at the end of 2006. Overall, the South African Government has demonstrated its commitment towards growing a biodiesel industry by announcing an increase in the fuel levy rebate to $40 \%$ for biodiesel producers. The possibility of a capital grant for developers of renewable energy resources are also being discussed within Government [9].

\subsection{Objectives of the paper}

Scientific research on the economic feasibility of biodiesel production has mainly focused on large industrial-scale operations. In contrast, the focus of the research summarised in this paper was on small-scale, on-farm biodiesel production systems that provide an opportunity to create systems whereby oil seed and biodiesel production are vertically integrated into a single value-chain. In this way larger percentages of the realisable profits can be retained on the farm or within the agricultural production community.

The objective of the study was to analyse the performance of such integrated small-scale, on-farm biodiesel production systems through the development of a model. The Biodiesel Production System Optimisation Model (BPSOM) derives the economic benefit obtained by vertically integrating the value chain components on the input and output sides of a small-scale biodiesel production facility. On the input or supply side the component is the oilseed production system of the farm; on the output side the components are the consumption of the oilcake by a livestock 
production system and the biodiesel for utilisation on the farm. BPSOM was validated with a case study of a farm in South Africa.

\section{The introduced Biodiesel Production System Optimisation Model (BPSOM)}

A model has been proposed [10] to evaluate the economic feasibility of a standalone biodiesel plant with an annual production capacity of 1.9 million litres. The model determines the cost to produce a litre of biodiesel based on the real cost of constructing and operating the plant, less the credits received for selling by-products, and divided by the total annual production in litres. The model considers the capital cost of oil extrusion and etherification equipment as the major contributors to capital expenditure. Capital costs and working capital is annualised before it is included in the total cost. The model is used to evaluate the impact of variability in key cost factors on the final biodiesel price per litre. The cost of oilseed and oilseed meal are determined as the two primary cost drivers [11]. Other factors such as chemical and labour costs have a relatively small impact in comparison.

Twelve economic feasibility studies on biodiesel production facilities have been reviewed [12], ranging from community-based to large-scale industrial facilities. Cost factors were generalised to enable a comparison between the different studies. These cost factors, on a cost-per-litre basis, are:

- $\quad$ Feedstock cost;

- $\quad$ Real annual capital cost (15 year book life);

- $\quad$ Operating costs;

- $\quad$ Chemical costs;

- $\quad$ Glycerine credits; and

- $\quad$ Oilcake credits.

The major limitation of these types of models is that they represent standalone facilities of which the impact on an integrated production system are not considered. In this research study [13] the 
limitation was overcome through the introduction of an optimal whole-farm planning model to obtain the impact on total production system profitability.

The resultant model, the on-farm Biodiesel Production System Optimisation Model (BPSOM) (see Figure 1), is capable of evaluating the feasibility of integrating an on-farm biodiesel production facility into a mixed crop-livestock production system. The model is a mathematical representation of the production system being evaluated and consists of the following components [13]:

- $\quad$ An on-farm biodiesel production facility model for evaluating the economic feasibility of biodiesel production;

- A mathematical, linear programming model for production system optimisation; and - An empirical model that defines the set of variables that will be modelled and the relevant constraints.

The biodiesel production facility model consists of three sections: the plant (capital and operational), feedstock and taxation costs. The costs are factored to present a final cost per litre biodiesel produced.

The standard linear programming algorithm for the production optimisation calculations of BPSOM is described by the following equation:

Maximise $Z=\sum_{j=1}^{n} C_{j} X_{j}, j=1, \ldots, n$, subject to:

$\sum_{i=1}^{m} a_{i j} x_{j} \leq b_{i}$, for all $i=1,2, \ldots, m$ and $X j \geq 0$, for all $j=1,2, \ldots, n$, where:

$Z$ = aggregate cash income (i.e. gross returns less variable costs);

$\mathrm{C}_{\mathrm{j}}=$ cash income over variable cost for the $j^{\text {th }}$ farm activity;

$\mathrm{X}_{\mathrm{j}}=$ level of $j^{\text {th }}$ farm activity; 
$a_{i j}=$ level of the $i^{\text {th }}$ input or resource needed to generate one unit of farm activity $X j$;

$b_{i}=$ quantity available of the $i^{\text {th }}$ resource;

$\mathrm{n}=$ number of farm activities; and

$m=$ number of constraints.

The model calculates the optimised production profit generated by the integrated crop, biodiesel and livestock production processes. A proxy measure, profit per hectare cultivated land, is introduced as a generalised measure that is used to compare profit generated before and after the introduction of the biodiesel production facility in the integrated production system.

\section{Research methodology}

The BPSOM was validated by means of case study research. The motivation for selecting the case study methodology, and the associated disadvantages, are:

- $\quad$ The BPSOM requires a large number of farm input variables that may have case specific interdependencies. Case study research allows for collecting the variable input and applying it in the context of the specific case by acknowledging the dependencies that exists. In instances where the rigidity of the model does not allow for the dependency to be included, assumptions had to be made and the variables adjusted. Such instances highlight shortcomings in the model for future enhancement.

- $\quad$ The purpose of the BPSOM is to be able to assess the economic viability of case-specific biodiesel production facilities. The BPSOM output will therefore never be generalisable, but will rather be specific to the business case in which it is applied. It is therefore also appropriate to test the model in the context of specific cases. Utilisation of the BPSOM will therefore also be limited to the cases similar to those used in the validation of the model, namely small-scale, on-farm biodiesel production facilities, where the farm is diversified in crop and livestock production. A wider application will only be obtained with further validation of the model in the wider context. 
- $\quad$ Validating the model by means of case studies provides an opportunity to assess the rigidity of the model by means of real data from the cases. The model outputs are in this way assessed for reasonability.

A farming operation that is situated near the town Greyton in the Western Cape Province of South Africa, traditionally a canola producing area, was selected for the case study. The farm produces a variety of crops, of which one is canola, cattle and sheep. The information required for the validation was identified and structured into a set of questions that was posed to the farmer during a site visit to the farm. The questions and related answers are summarised in Tables 1 and 2.

Information on the capital cost of biodiesel facilities were obtained from Biodiesel One [14], a South African based company that specialises in the construction and marketing of small-scale biodiesel production facilities. The information for four facilities with increasing capacity is summarised in Table 3. The typical operating costs for small-scale, batch reactors is approximately $\mathrm{R} 0.15$, or around 2 US cents (as at the end of 2006 and in 2011), per litre of biodiesel produced [14]. This cost includes labour, water and electricity. The costs were not indicated to be scale dependant, which correlates with previously reviewed models [12].

The chemical costs per litre biodiesel produced will range from $R 0.70$ to $R 1.00$ depending on the quality of oil used in the process [14]. Old vegetable oils and used cooking oil contains larger quantities of free fatty acids and impurities that require additional amounts of chemicals to complete the transesterification process $[3,14]$. A cost of $R 0.95$ for chemicals per litre biodiesel can be assumed at 2006 market prises [15].

The validation of BPSOM comprised of two methods. The first method was constructed to validate the output of the biodiesel production facility model to ensure the cost per litre biodiesel predicted by the model is reliable. Two tests were selected to validate the model output [16]: 
Mean Absolute Deviation (MAD):

$$
M A D=\frac{\sum_{j=1}^{N}\left|X_{j}^{p}-X_{j}^{a}\right|}{N}
$$

where $X_{j}^{p}=$ predicted value of activity or variable $X_{j}, X_{j}^{a}$ is the actual value of $X_{j}$, and $N$ is the total number of variables under consideration.

Theil Index (TI):

$\mathrm{TI}=\frac{\left[\frac{1}{N} \cdot \sum_{j=1}^{N}\left(X_{j}^{p}-X_{j}^{a}\right)^{2}\right]^{0.5}}{\left[\frac{1}{N} \cdot \sum_{j=1}^{N}\left(X_{j}^{p}\right)^{2}\right]^{0.5}+\left[\frac{1}{N} \cdot \sum_{j=1}^{N}\left(X_{j}^{a}\right)^{2}\right]^{0.5}}$

where the variables are as defined previously.

Small values for the MAD test suggest a desirable mathematical model [16]. A TI close to zero suggests a good model as it indicates a correspondence between the predicted and actual values for $X$ for all $j=1,2, \ldots, n$.

The second validation method was constructed to evaluate the impact of introducing a biodiesel production facility into the existing production system of the case study farm. The information used for the test case was obtained from Tables 1 to 3 .

\section{Research findings}

The biodiesel production facility model output predicts that the total cost per litre biodiesel produced from a biodiesel facility with an annual capacity of 300000 litres (1500 litres per day) is $R$ 4.61, or approximately 66 US cents, at the end of 2006 . This was R 0.79 less than the price of petroleum 
diesel using sunflower seed as feedstock at 2006 market prices. Previous calculations [15] indicated that the cost per litre biodiesel would be R 1.46 less than the petroleum diesel price. The price difference is likely due to the annualised capital cost of the facility that was included in the calculations of this study [13]. The final cost per litre biodiesel does not include fuel levies due to the tax exemption that applies to biodiesel producers in South Africa with a capacity of less than 25000 litres per month [17].

The modelled output for the first validation method is shown in Figure 2. This output was used to calculate the MAD and TI values as described in section 3 . The results for the respective measures are:

1. Mean absolute deviation (MAD) $=0.45$

2. Theil index $(\mathrm{TI})=0.088$

The small values for the MAD and PAD measures suggest that the mathematical model presents desirable results [16]. The Thiel Index value close to zero indicates that the predicted final cost per litre biodiesel produced correlates with the actual values published [15] although the results are based on limited information, namely one set of predicted data points and one set of reference data points. The input values used in calculating the MAD and TI values are provided in Table 4.

Figures 3 and 4 illustrate the output produced by the BPSOM based on the input data that was prepared for the second validation method. The final cost per litre biodiesel is $R 2.38$, which is significantly lower than previously published values published $[8,15]$. The lower cost is attributed to the fact that the canola seed is supplied to the biodiesel facility in the farm case study at production cost whereas the values in literature assumed market related prises.

The capacity of the biodiesel production facility required by the case study farm to supply for its own consumption and the demand on neighbouring farms is limited to 150000 litres per annum. This will 
slightly increase the capital cost per litre biodiesel produced during the first five years of operation of the facility, namely during the assumed loan period. The cost increase will, however, not significantly impact the profitability of the system [13]. From a practical consideration this does allow the farmer to operate the plant at less than optimum levels in a way that fits in with the operating system on the farm, namely operation for only three days a week and not during peak periods such as harvesting.

The BPSOM indicates that it may be profitable for the case study farm to introduce a biodiesel production system into the current crop and livestock production systems. The amount of biodiesel produced and the hectares of canola cultivated are constraint by the market for biodiesel sold to neighbouring farmers. The model indicates that only 260 hectares of canola should be cultivated due to this constraint. However, it will still be profitable for the farmer to cultivate the full 300 hectares set aside for canola in the rotational plan. The introduction of the biodiesel production facility into the production operations of the case study farm increases the income per hectare cultivated land from R 2068 to R 2 761, an increase of 33\%.

\section{Conclusions and recommendations}

A Biodiesel Production System Optimisation Model (BPSOM) was developed through the undertaken research summarised in this paper [13]. The model consists of two primary calculations:

1. A simplified model for calculating the cost of producing biodiesel using oilseed feedstock and the generic batch process of transesterification; and

2. A linear programming calculation that determines how the biodiesel production facility can be optimally integrated into the existing farming operations to maximise profits.

The BPSOM was validated by means of two methods that were set up using data gathered from a case study farm in the Western Cape Province of South Africa. The validation methods established that the biodiesel production costs predicted by the model compares favourably with those reported 
in literature. The study further introduced a proxy measure of profitability per hectare cultivated land to measure pre- and post-implementation profitability of the optimised farming production system. The measure indicated that a small-scale biodiesel production facility may have a positive economic effect on the total profitability of the specific farming production system. In terms of practical considerations the variability of the cost of feedstock and the price received for oilcake would considerably affect the feasibility. The farmer could mitigate the risk by signing contracts with neighbouring farmers to buy the surplus biodiesel and oilcake. Furthermore, the impacts that the biodiesel facility may have on other operations was not considered, namely additional management requirements, training of personnel, and quality aspects of the produced biodiesel.

Due to the limited scope of the validation tests performed on the BPSOM, it is recommended that the model be verified with additional case studies to establish the generalisability of the model, both inside and outside South Africa. Furthermore, the usefulness of the model will be improved if a simple methodology for applying the model in biodiesel business case investigations can be ascertained.

The BPSOM was developed to assess the economic feasibility of small-scale, on-farm biodiesel facilities that are integrated with current production systems on farms that are diversified in crop and livestock production. The potential of introducing alternative crops and or production processes was not considered by the study. The BPSOM can, however, be easily adapted to serve as a tool to compare different scenarios where new oil crops such as Jatropha Curcas are introduced specifically for biofuels production [18]. 


\section{References}

[1] Van Gerpen J. Biodiesel processing and production. Fuel Processing Technology 2005; 86: 1097-1107.

[2] Meher LC, Vidya Sagar D, Naik SN. Technical aspects of biodiesel production by transesterification - a review. Renewable and Sustainable Energy Reviews 2006; 10: 248268.

[3] Van Gerpen J. Business management for biodiesel producers. National Renewable Energy Laboratory, Colorado: US Department of Energy; 2004.

[4] Fortenbery TR. Biodiesel feasibility study: An evaluation of biodiesel feasibility in Wisconsin. University of Wisconsin-Madison: Department of Agricultural and Applied Economics; 2005, available from http://aae.wisc.edu/pubs/sps/pdf/stpap481.pdf.

[5] Van Gerpen J, Pruszko R, Clements D, Shanks B, Knothe G. Building a successful biodiesel business. Second edition. Illinois: American Oil Chemists' Society; 2006.

[6] Dornburg V, van Dam J, Faaij A. Estimating GHG emission mitigation supply curves of largescale biomass use on a country level. Biomass and Bioenergy 2007; 31: 46-65.

[7] Moodley N. Biofuels strategy approved for consultation. Engineering News 2006; available from http://www.engineeringnews.co.za.

[8] Jooste C. Saaiboer maak eie diesel. Landbou Weekblad 2005; available from http://www.landbou.com/LandbouWeekblad/Home/.

[9] Salgado I. Subsidies are mooted for renewable energy producers. Business Report 2006; available from http//www.busrep.co.za.

[10] Weber JA. The economic feasibility of community based biodiesel plants. Masters Thesis, Columbia: University of Missouri-Columbia; 1993.

[11] Weber JA, van Dyne DL. Macroeconomic effects of a community based biodiesel production system. In Dale BE (ed). Liquid Fuels, Lubricants and Additives from Biomass. Proceedings of an Alternative Energy Conference, American Society of Agricultural Engineers, St. Joseph, Missouri 1994; 77-84. 
[12] Bender M. Economic feasibility review for community-scale farmer cooperatives for biodiesel. Bioresource Technology 1999; 70: 81-87.

[13] Pienaar J. A model for evaluating the economic feasibility of farm-scale biodiesel production systems. Masters Thesis, Pretoria: University of Pretoria; 2006, available from http://www.up.ac.za/gstm.

[14] Nieuwoudt, O. 2006. Personal and email communication on 4 September 2006. Email: nieuwoudtha@telkomsa.net

[15] Van Rooyen C. Biobrandstof reeds die moeite werd. Landbou Weekblad 2006; available from http://www.landbou.com/LandbouWeekblad/Home/.

[16] Yiridoe EK, Langyintuo AS, Dogbe W. Economics of the impact of alternative rice cropping systems on subsistence farming: Whole-farm analysis in northern Ghana. Agricultural Systems 2006; in press.

[17] Coetzee J. 2006. Biobrandstof: Klim nou in. Landbou Weekblad 2006; available from http://www.landbou.com/LandbouWeekblad/Home/.

[18] Holtzhausen L. Investigations on track into impacts of 'bio-diesel' tree. Water Wheel 2005; September-October: 14-17. 
Figure 1. Schematic of the BPSOM.

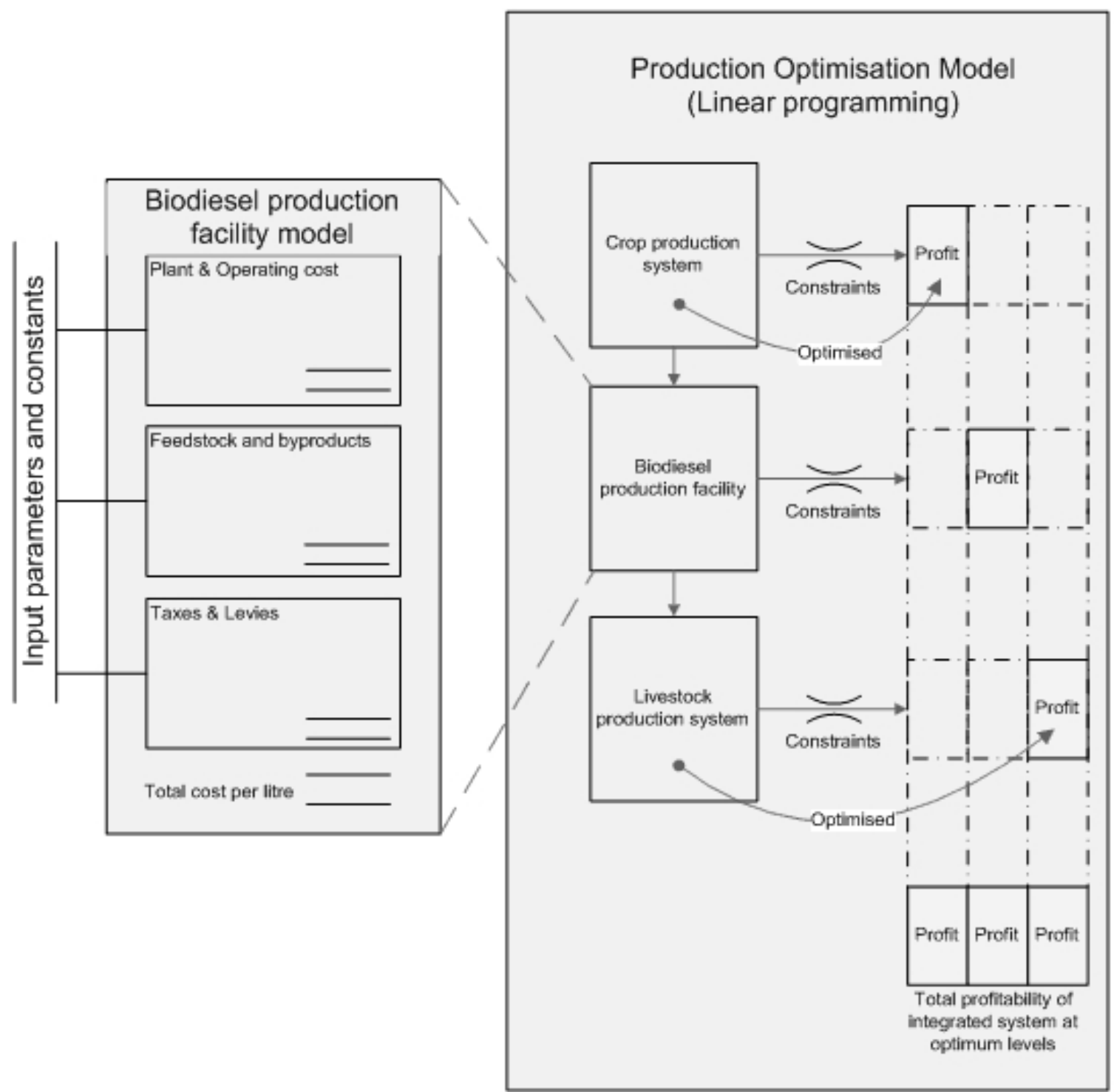


Figure 2. BPSOM output for the first validation method.

\begin{tabular}{|c|c|c|c|}
\hline \multicolumn{3}{|l|}{ Plant (Capital and Operating) } & \multirow{2}{*}{$\begin{array}{l}\text { Notes: } \\
\text { Input }\end{array}$} \\
\hline Plant capacity (litres per year) & 300000 & & \\
\hline Capital cost & R 519200.00 & & {$[14]$} \\
\hline Annual payment on capital investment & R 142251.34 & & Calculated \\
\hline Prime interest rate & $11.5 \%$ & & Case study \\
\hline Loan period (years) & 5 & & Case study \\
\hline Capital cost per litre annual capacity & & R 0.47 & Calculated \\
\hline Operational cost per litre & & R 0.15 & {$[14]$} \\
\hline Chemicals cost per litre & & R 0.95 & [14] \\
\hline Sub-total & & R 1.57 & \\
\hline \multicolumn{3}{|l|}{ Feedstock and by-products } & \multirow{9}{*}{$\begin{array}{l}{[12,14]} \\
{[15]} \\
\text { Calculated } \\
{[12,14]} \\
{[15]} \\
\text { Calculated } \\
{[15]}\end{array}$} \\
\hline $\mathrm{Kg}$ oilseed per litre & 2.9 & & \\
\hline Oilseed production cost (per ton) & R 2175.00 & & \\
\hline Cost per litre & & R 6.40 & \\
\hline Oil cake (kg per litre) & 1.9 & & \\
\hline Price per ton & $R-1700.00$ & & \\
\hline Credit per litre & & $R-3.30$ & \\
\hline Glycerol credit per litre & & $R-0.06$ & \\
\hline Sub-total & & R 3.04 & \\
\hline \multicolumn{3}{|l|}{ Fuel Taxes } & \multirow{4}{*}{ [17] } \\
\hline Fuel levy on diesel & & n.a. & \\
\hline Less $40 \%$ tax concession & & n.a. & \\
\hline Total cost per litre biodiesel & & R 4.61 & \\
\hline
\end{tabular}

7 South African Rand (R) is equal to approximately 1 US\$ (as at the end of 2006 and in 2011). 
Figure 3. BPSOM output for the second validation method (cost per litre biodiesel produced).

Plant (Capital and Operating)

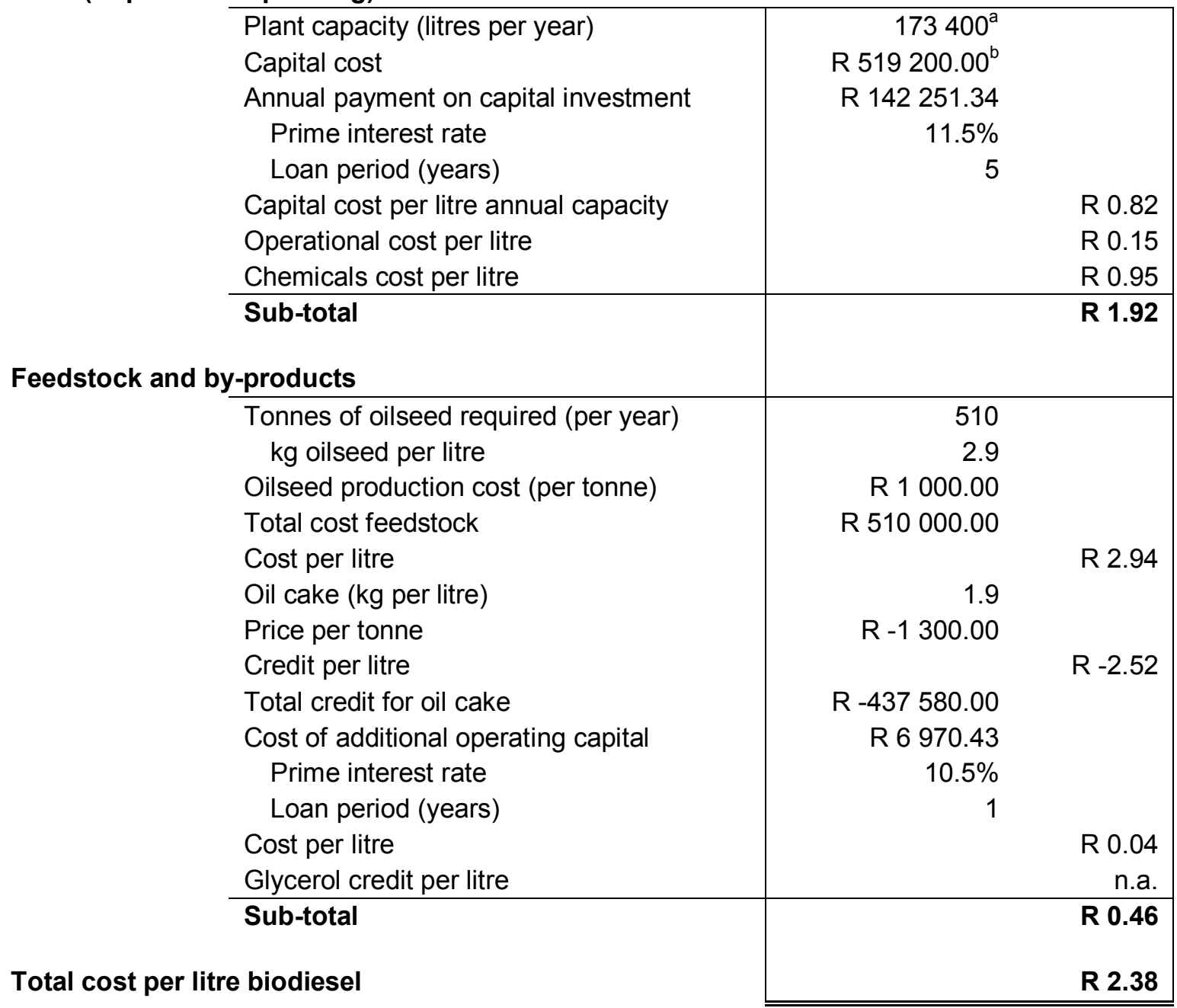

7 South African Rand (R) is equal to approximately 1 US\$ (as at the end of 2006 and in 2011).

a Litres of biodiesel that can be produced from the 510 tonne canola produced on the farm.

b Cost of a 300000 litre per annum plant. 
Figure 4. BPSOM output for the second validation method (income per hectare cultivated land).

\section{Crop production}

Crops produced

Hectares cultivated

Tonnes produced

Average yield

Unit price

Production cost

Unit profit contribution

\begin{tabular}{|r|r|}
\multicolumn{1}{c}{ Canola } & \multicolumn{1}{c}{ Other } \\
\hline 260 & 1100 \\
441 & 3180 \\
1.7 & 2.9 \\
R 1920 & $\mathrm{R} 1502$ \\
R 1 000 & $\mathrm{R} 764$ \\
R 920 & $\mathrm{R} 738$ \\
\hline
\end{tabular}

Notes:

Optimised

Calculated

Case study input

Case study input

Case study input

Case study input

Calculated

Calculated

Case study input

Case study input

Calculated

Model input

Case study input

Calculated

Calculated

Case study input

Optimised

Calculated

Case study input

Case study input

Livestock production

Units produced

Oilcake required (tonne)

Per unit (kg)

Unit profit contribution

\begin{tabular}{|r|}
300 \\
54 \\
180 \\
$\mathrm{R} 1000$ \\
\hline
\end{tabular}

Resource constraints

Hectares available for Canola

Market for feedlot cattle

Oilcake used in feedlot (tonne)

Biodiesel offset market (litres)

\begin{tabular}{|r|r|}
\multicolumn{1}{c}{ Used } & \multicolumn{1}{c}{ Available } \\
260 \\
300 \\
54 \\
112500 \\
300 \\
300 \\
291 \\
112500 \\
\hline
\end{tabular}

Case study input Case study input Case study input Case study input

\section{Production Profit}

Crop production

Biodiesel production

Livestock production

Total
R 2751732

R 701317

R 300000

R 3753049
Income per hectare cultivated land Excluding biodiesel income
R 2761

R 2245 
Table 1. Case study questions and answers.

\begin{tabular}{|c|c|}
\hline Question & Answer \\
\hline $\begin{array}{l}\text { 1. At what interest rate can finance be arranged for } \\
\text { purchasing and construction of a biodiesel facility? } \\
\text { What will the typical loan period be? Will this be } \\
\text { determined by the bank or the farmer? Would it be } \\
\text { necessary for the farming operation to obtain such } \\
\text { a loan or could it make use of reserve funds? }\end{array}$ & $\begin{array}{l}\text { The farm has access to normal asset finance from a } \\
\text { commercial bank at the prime interest rate }(11.5 \%) \text { The loan } \\
\text { period will likely be set on } 5 \text { years, given the risk involved and } \\
\text { the nature of the assets being financed. Any period shorter } \\
\text { than } 5 \text { years will be too costly in terms of annual payments. A } \\
\text { positive return on investment is expected after } 5 \text { years. }\end{array}$ \\
\hline $\begin{array}{l}\text { 2. Provide a summary of the crops and livestock } \\
\text { produced on the farm. Indicate the number of } \\
\text { hectares per each of the crops produced and the } \\
\text { total number of hectares available for cultivation. } \\
\text { Also indicate the long term average yield per crop. }\end{array}$ & $\begin{array}{l}\text { Refer to Table 2. The total amount of hectares (1400) } \\
\text { available for cultivation is currently utilised. Cattle and sheep } \\
\text { are also produced on the areas allocated for grazing on the } \\
\text { farm. A feedlot is used to fatten calves for sale at the local } \\
\text { auction pens. }\end{array}$ \\
\hline $\begin{array}{l}\text { 3. Provide the input costs per each of the crops } \\
\text { listed in question 2, the current market price and } \\
\text { the expected profit margin. }\end{array}$ & $\begin{array}{l}\text { Refer to Table } 2 . \text { The expected profit per head of cattle is } \\
\text { R1000. }\end{array}$ \\
\hline $\begin{array}{l}\text { 4. Indicate the constraining factors that limit the } \\
\text { farming operation to the activities provided above } \\
\text { i.e. operating capital, mechanisation or the size of } \\
\text { the farm. }\end{array}$ & $\begin{array}{l}\text { The only constraining factor is the number of hectares } \\
\text { available to cultivate. Operating capital is not a constraint. } \\
\text { Machinery can be rented during peak demand periods. }\end{array}$ \\
\hline $\begin{array}{l}\text { What is the current cost of canola oilcake when } \\
\text { bought in and at what price would the farm be } \\
\text { able to market oilcake should it not utilise all of the } \\
\text { cake produced in the biodiesel production } \\
\text { process? }\end{array}$ & $\begin{array}{l}\text { The cost of Canola oilcake is estimated at R } 2500 \text { per ton. } \\
\text { The only Canola oil press in the district is situated at the town } \\
\text { of Swellendam, which is approximately } 100 \text { kilometres from } \\
\text { the farm. Oilcake produced in the biodiesel production process } \\
\text { will be sold to neighbouring farmers at a reduced price. The } \\
\text { market prise for Canola oilcake was confirmed with Epol } \\
\text { foods, in the capital Pretoria as R } 1400 \text { per ton. }\end{array}$ \\
\hline $\begin{array}{l}\text { 6. What is the capacity of the cattle feedlot on the } \\
\text { farm? How many cattle can be produced in the } \\
\text { feedlot on an annual basis given other } \\
\text { constraining factors on the farm? Is one of these } \\
\text { constraining factors the total hectares of pastures } \\
\text { available for cattle to graze? How will this } \\
\text { constrain the biodiesel production process? }\end{array}$ & $\begin{array}{l}\text { The capacity of the cattle feedlot will not be a constraint for the } \\
\text { utilisation of the Canola oilcake. The available grazing land will } \\
\text { also not be a constraint as the additional cattle introduced to } \\
\text { consume the oilcake will be bought in from neighbouring } \\
\text { farms. Cattle will typically be fed in the feedlot for a period of } 6 \\
\text { months before being marketed. The average amount of } \\
\text { Canola oilcake included in a feedlot ration for cattle amounts } \\
\text { to } 1 \text { kilogram per head of cattle per day. }\end{array}$ \\
\hline $\begin{array}{l}\text { 7. Will it be necessary for the farming operation to } \\
\text { obtain additional operating capital from a financier } \\
\text { to bridge the period during which the oilseed crop } \\
\text { is tied up in the biodiesel production presses? }\end{array}$ & $\begin{array}{l}\text { It will not be necessary to obtain additional operating capital to } \\
\text { implement a biodiesel production facility. Should it however be } \\
\text { required the cost would be at prime less } 1 \% \text {, or } 10.5 \% \text {. A } \\
\text { reasonable period to allow for will be } 1 \text { year after which the } \\
\text { farming operation will have compensated for the initial } \\
\text { operational cost in its annual budget. }\end{array}$ \\
\hline $\begin{array}{l}\text { 8. What is the total number of litres biodiesel that the } \\
\text { farm can utilise per year? Will it be mixed with } \\
\text { conventional petroleum diesel and at what ratio? } \\
\text { Can the farms current machinery be operated on } \\
\text { biodiesel? }\end{array}$ & $\begin{array}{l}\text { The farm uses } 75000 \text { litres of diesel per year. The diesel is } \\
\text { currently bought from a distributor at R } 6.64 \text { per litre. The farm } \\
\text { is entitled to a diesel rebate of } R 0.70 \text { per litre on } 80 \% \text { of the } \\
\text { litres used per annum. The average cost per litre then equates } \\
\text { to } R 6.08 \text {. } \\
\text { The farmer expects to be able to replace at least } 50 \% \text { of his } \\
\text { petroleum diesel with biodiesel. }\end{array}$ \\
\hline $\begin{array}{l}\text { 9. If there is a surplus of biodiesel produced, can this } \\
\text { be sold to nearby farms? At what price will it be } \\
\text { sold? }\end{array}$ & $\begin{array}{l}\text { Surplus biodiesel will be sold to neighbouring farmers at cost } \\
\text { plus } 10 \% \text {. }\end{array}$ \\
\hline
\end{tabular}


Table 2. Crops produced, yield and profit margin for the farm case study.

\begin{tabular}{|c|c|c|c|c|c|}
\hline Crop & $\begin{array}{l}\text { Hectares } \\
\text { cultivated }\end{array}$ & $\begin{array}{l}\text { Average yield } \\
\text { per hectare } \\
\text { (ton) }\end{array}$ & $\begin{array}{c}\text { Input cost } \\
\text { per hectare } \\
(2006)\end{array}$ & $\begin{array}{c}\text { Market prise } \\
\text { per ton }^{\mathrm{a}} \\
(2006)\end{array}$ & $\begin{array}{l}\text { Profit per } \\
\text { ton }^{\mathrm{a}}\end{array}$ \\
\hline Wheat & 550 & 3 & R 2400 & R 1600 & R 800 \\
\hline Barley & 350 & 3 & R 2400 & R 1600 & $\mathrm{R} 800$ \\
\hline Canola & 300 & 1.7 & R 1700 & R 1920 & R 920 \\
\hline Oats & 100 & 2.7 & R 1500 & R 1055 & R 500 \\
\hline Lupines & 50 & 1.5 & R 1500 & R 1200 & R 200 \\
\hline Rye & 50 & 2.7 & R 900 & R 600 & R 300 \\
\hline
\end{tabular}


Table 3. Capital cost of small-scale biodiesel facilities.

\begin{tabular}{|c|c|c|c|c|}
\hline $\begin{array}{l}\text { Plant capacity } \\
\text { (litres per year) }\end{array}$ & 300000 & 600000 & 1200000 & 1500000 \\
\hline Transesterification equipment & R 97000 & R 145000 & R 235000 & R 270000 \\
\hline Oil press & R 40000 & R 67500 & R 122500 & R 150000 \\
\hline Diesel storage tanks & R 15000 & R 30000 & R 60000 & $\mathrm{R} 75000$ \\
\hline Chemical storage & R 20000 & R 30000 & R 45000 & R 50000 \\
\hline Grain storage silos & R 300000 & R 450000 & R 730000 & R 835000 \\
\hline Contingencies (10\%) & R 47200 & R 72250 & R 119250 & R 138000 \\
\hline Total capital cost & R 519200 & R 794750 & R 1311750 & R 1518000 \\
\hline Cost per litre capacity & R 1.73 & R 1.32 & R 1.09 & R 1.01 \\
\hline
\end{tabular}

7 South African Rand (R) is equal to approximately 1 US\$ (as at the end of 2006 and in 2011). 
Table 4. Input variables and values for validity tests.

\begin{tabular}{|c|c|c|c|}
\cline { 2 - 4 } \multicolumn{1}{c|}{} & $\begin{array}{c}\text { Total cost per } \\
\text { litre biodiesel }\end{array}$ & $\begin{array}{c}\text { Differential } \\
\text { cost of } \\
\text { feedstock }\end{array}$ & $\begin{array}{c}\text { Cost difference } \\
\text { compared to } \\
\text { petroleum diesel }\end{array}$ \\
\hline$N$ & 1 & 2 & 3 \\
\hline$X_{j}^{p}$ & $\mathrm{R} 4.61$ & $\mathrm{R} 3.04$ & $\mathrm{R} 0.79$ \\
\hline$X_{j}^{a}$ & $\mathrm{R} 3.94$ & $\mathrm{R} 3.05$ & $\mathrm{R} 1.46$ \\
\hline
\end{tabular}

